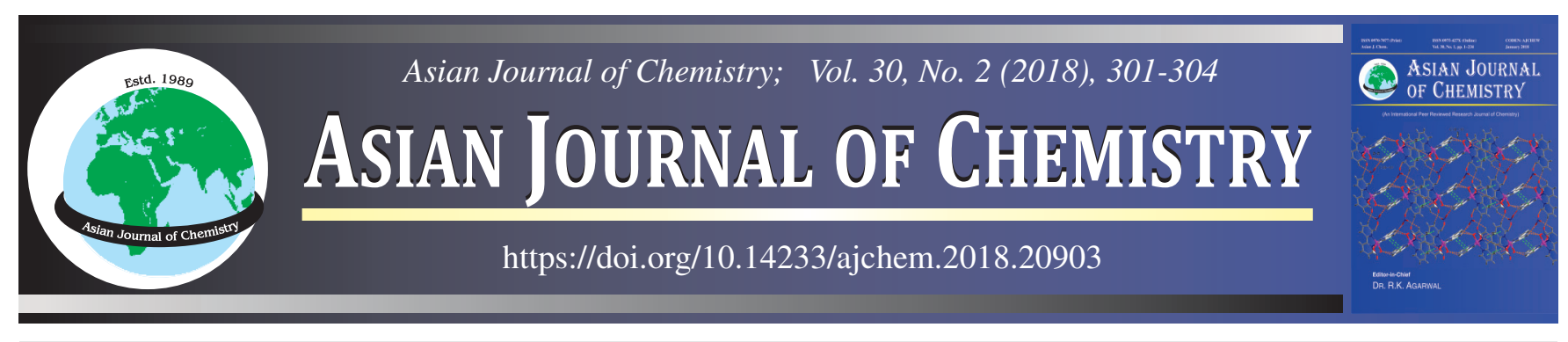

\title{
RP-HPLC Method for Estimation of Ado-Trastuzumabe Emtansine Injection in Pharmaceutical Dosage Form
}

Abaddhamu Chintapilli ${ }^{1}$, K. Satyavathi ${ }^{1}$, P. Bhojaraju $^{1}$, Lakshmi Kanta Kanthal ${ }^{2, *}$ and Sreejan Manna ${ }^{3}$

${ }^{1}$ Department of Pharmaceutical Analysis \& Quality Assurance, Koringa College of Pharmacy, Korangi-533 461, India

${ }^{2}$ Faculty of Pharmacy, DIT University, Mussoorie Diversion Road, Makkawala, Salan Gaon, Bhagwant Pur, Dehradun-248 009, India

${ }^{3}$ Gupta College of Technological Sciences, Ashram More, Asansol-713 301, India

*Corresponding author: Tel/Fax: +91 884 2304387; E-mail: 1kkhaldia@gmail.com

\section{INTRODUCTION}

The antibody-drug compound ado-trastuzumab emtansine (T-DM1) is integrate the anticancer substances which is a potent microtubule-disrupting drug and linked by a stable coupler of the humanized anti-human epidermal growth factor receptor 2 (HER2) antibody, trastuzumab, with the maytansinoid, DM1 [1-3]. Therefore attached to HER2, the compound is internalized via receptor-mediated endocytosis and an active derivative of DM1 is eventually delivered by proteolytic degradation of the antibody moiety within the lysosome $[1,4]$. HER 2-positive and metastatic breast carcinoma treatment is possible by this agent who have hitherto used taxane or trastuzumab. Ado-trastuzumab emtansine has a lengthy biological half-life of about 4 days [5].

The objective of the present study is to develop and validate a HPLC method for ado-trastuzumab emtansine pharmaceutical dosage form to be indenture in routine analysis [6]. In the method development of ado-trastuzumab emtansine we have incorporating the reverse phase high performance liquid chromatography (HPLC). Then the developed method will be validated according to ICH guidelines for its various parameters [7-9].

\section{EXPERIMENTAL}

Ado-trastuzumab emtansine was obtained as a gift sample from Hetero Labs Limited, Hyderabad, Telangana, India. HPLC grade methanol and water were purchased from Merck, India and Loba Chemie Pvt. Ltd., India, respectively. All the other chemicals used were of analytical grade purchased from Finar chemicals, India.

HPLC instrumentation and conditions: Quantitative HPLC was performed on WATERS HPLC, model: Agilent 2695, photo diode detector (PDA), with an automated sample injector. The output signal was monitored and integrated using Empower 2 software. Phenomenex C18 $(150 \mathrm{~mm} \times 4.6 \mathrm{~mm} \times 5 \mu \mathrm{m})$ column was used for separation, maintained at $25^{\circ} \mathrm{C}$, eluted with mobile phase at a flow rate of $1.1 \mathrm{~mL} / \mathrm{min}$ for $10 \mathrm{~min}$. The mobile phase consisted of $0.1 \mathrm{M}$ potassium dihydrogen phosphate $\left(\mathrm{KH}_{2} \mathrm{PO}_{4}\right)$ and methanol in the proportion of 55: $45 \%(\mathrm{v} / \mathrm{v})$. Measurements were made with injection volume $8 \mu \mathrm{L}$ and $\mathrm{UV}$ detection at $242 \mathrm{~nm}$.

Preparation of mobile phase: $0.1 \mathrm{M}$ Potassium dihydrogen phosphate $\left(13.608 \mathrm{~g}\right.$ of $\mathrm{KH}_{2} \mathrm{PO}_{4}$ was added to $1000 \mathrm{~mL}$ of HPLC water to make $0.1 \mathrm{M}$ solution of $\mathrm{KH}_{2} \mathrm{PO}_{4}$ ) and methanol were mixed properly in the ratio of 55:45. 


\section{Preparation of standard and sample solutions}

Standard solution: The standard stock solution of adotrastuzumab emtansine $(1 \mathrm{mg} / \mathrm{mL})$ was prepared by dissolving $100 \mathrm{mg}$ of ado-trastuzumab emtansine in $100 \mathrm{~mL}$ volumetric flask containing $20 \mathrm{~mL}$ of methanol and sonicated for $10 \mathrm{~min}$ and made up with water. From the above solution, $2.5 \mathrm{~mL}$ was transferred into a $25 \mathrm{~mL}$ volumetric flask and diluted up to the mark with water.

Sample solutions: $5 \mathrm{~mL}$ of commercially available pharmaceutical dosage form of Ado-Trastuzumab emtansine (Kadcyla Injection) equivalent to $100 \mathrm{mg}$ of ado-trastuzumab emtansine was transferred into a $100 \mathrm{~mL}$ volumetric flask and $20 \mathrm{~mL}$ of methanol was added and sonicated for 20 min and made up with water. From the above solution, $2.5 \mathrm{~mL}$ was transferred into a $25 \mathrm{~mL}$ volumetric flask and diluted up to the mark with methanol and solution was filtered through $0.45 \mu \mathrm{m}$ filter before injecting into HPLC system.

\section{RESULTS AND DISCUSSION}

Optimization of the method: The RP-HPLC method utilized Phenomenex C18 column $(150 \mathrm{~mm} \times 4.6 \mathrm{~mm} \times 5 \mu \mathrm{m})$ in an isocratic separation mode with mobile phase $0.1 \mathrm{M}$ potassium dihydrogen phosphate and methanol in the proportion of $55: 45 \%(\mathrm{v} / \mathrm{v})$, at a flow rate of $1.1 \mathrm{~mL} / \mathrm{min}$ and the effluent was monitored at $242 \mathrm{~nm}$. The retention time for ado-trastuzumab emtansine was 3.234 min (Fig. 1).

Method validation: The method has been validated for system suitability, specificity, accuracy, precision, linearity, robustness, limit of detection (LOD) and limit of quantitation (LOQ).

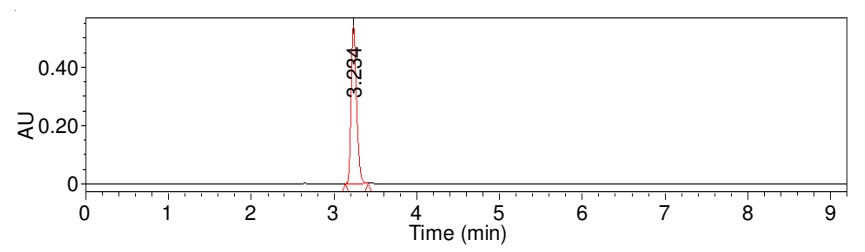

Fig. 1. Chromatogram for optimized method of ado-trastuzumab emtansine

System suitability: The system suitability parameters like retention time, theoretical plates, tailing factor were calculated and compared with the standard values whether the proposed RP-HPLC method for the estimation of ado-trastuzumab emtansine in pharmaceutical formulations was validated or not. The obtained value of retention time in this method was 3.224 min, theoretical plates were 10783 and tailing factor was found to be 1.28 .

Specificity: The time $\left(\mathrm{R}_{\mathrm{t}}\right)$ for standard, sample and commercial product of ado-trastuzumab emtansine were same (Rt $=3.22 \mathrm{~min}$ ). This proved that excipients have no effect on the analytical method.

Accuracy: The present study was performed at three levels in which sample stock solution was spiked with standard drug solution containing 50, 100 and $150 \%$ of labeled amount of drugs. Three replicate samples of each concentration level were prepared and the \% recovery at each level $(\mathrm{n}=3)$ and mean $\%$ recovery $(n=9)$ were determined (Table- 1 and Fig. 2$)$. The mean recovery was $100 \%$.

Precision: The precision of the proposed method was evaluated by carrying out six independent assays of test sample. Percentage relative standard deviation (\% RSD) was found to be less than $2 \%$ which proved that method was precise (Table-2 and Fig. 3).

TABLE-1

ACCURACY (\% RECOVERY) RESULTS OF ADO-TRASTUZUMAB EMTANSINE

\begin{tabular}{|c|c|c|c|c|c|c|}
\hline Accuracy level (\%) & Sample name & Sample weight & Added $(\mu \mathrm{g} / \mathrm{mL})$ & Found $(\mu \mathrm{g} / \mathrm{mL})$ & Recovery (\%) & Mean $(\%)$ \\
\hline \multirow{3}{*}{50} & 1 & 50.00 & 49.500 & 49.67 & 100 & \multirow{3}{*}{100} \\
\hline & 2 & 50.00 & 49.500 & 49.52 & 100 & \\
\hline & 3 & 50.00 & 49.500 & 49.72 & 100 & \\
\hline \multirow{3}{*}{100} & 1 & 100.00 & 99.000 & 99.16 & 100 & \multirow{3}{*}{100} \\
\hline & 2 & 100.00 & 99.000 & 99.42 & 100 & \\
\hline & 3 & 100.00 & 99.000 & 99.27 & 100 & \\
\hline \multirow{3}{*}{150} & 1 & 150.00 & 148.500 & 149.21 & 100 & \multirow{3}{*}{100} \\
\hline & 2 & 150.00 & 148.500 & 149.23 & 100 & \\
\hline & 3 & 150.00 & 148.500 & 149.29 & 101 & \\
\hline
\end{tabular}
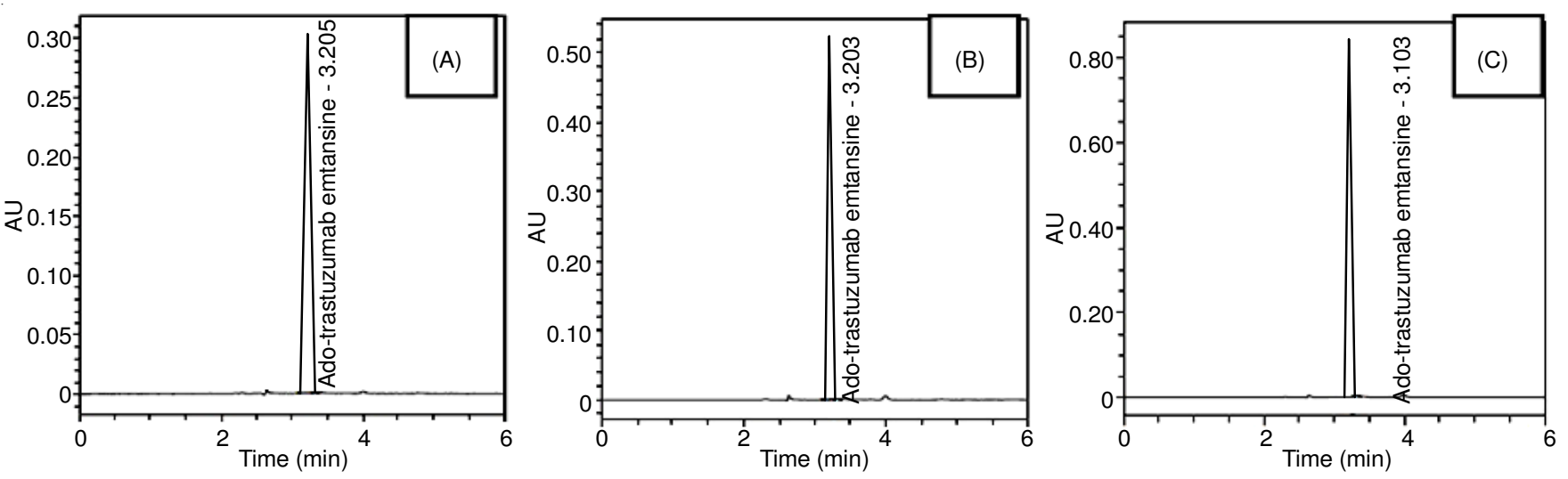

Fig. 2. Typical chromatogram for accuracy $50 \%$ (A), accuracy $100 \%$ (B) and accuracy $150 \%$ (C) 

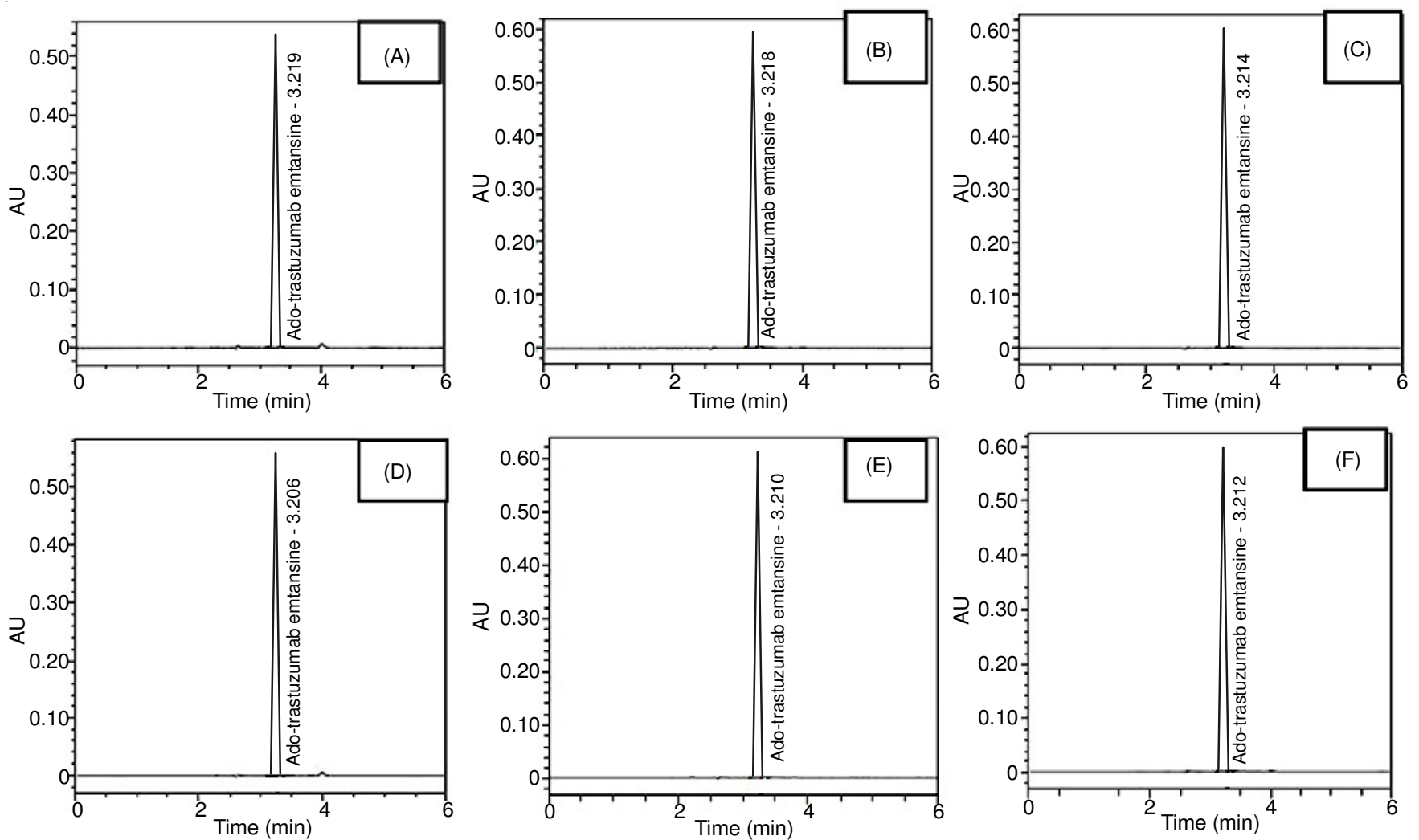

Fig. 3. Chromatogram for precision injection 1 (A), injection 2 (B), injection 3 (C), injection 4 (D), injection 5 (E) and injection 6 (F)

\begin{tabular}{cccc}
\multicolumn{5}{c}{ TABLE-2 } \\
\multicolumn{4}{c}{ PRECISION DATA FOR ADO-TRASTUZUMAB EMTANSINE } \\
\hline S. No. & $\mathrm{R}_{\mathrm{t}}$ & Area & Assay $(\%)$ \\
\hline Injection 1 & 3.219 & 2460978 & 99 \\
Injection 2 & 3.218 & 2465404 & 99 \\
Injection 3 & 3.214 & 2461769 & 99 \\
Injection 4 & 3.206 & 2460257 & 99 \\
Injection 5 & 3.210 & 2461567 & 99 \\
Injection 6 & 3.212 & 2466050 & 99 \\
\hline Mean & & & 99 \\
Std. Dev. & & & 0.10 \\
RSD (\%) & & & 0.10 \\
\hline
\end{tabular}

Linearity: A linear relationship between peak areas versus concentrations was observed for ado-trastuzumab emtansine in the range of 50 to $150 \mu \mathrm{g} / \mathrm{mL}$ of nominal concentration. Correlation coefficient was 0.999 for ado-trastuzumab emtansine which proved that the method was linear in the range of 50 to $150 \mu \mathrm{g} / \mathrm{mL}$.

Robustness: The results of robustness of the present method had shown that the changes made in the flow and temperature did not produce significant changes in analytical results which were presented in Table-3 and Fig. 4. So, the method conditions were robust.

LOD and LOQ: Minimum concentration of standard component in which the peak of the standard gets merged with noise is called as LOD (limit of detection) and minimum concentration of standard component in which the peak of the standard gets detected and qualified is called as LOQ (limit of quantitation). The formulae used were $\mathrm{LOD}=3.3 \mathrm{\sigma} / \mathrm{S}$ and LOQ $=$ $10 \sigma / \mathrm{S}$ (where $\sigma=$ standard deviation of response and $\mathrm{S}=$

\begin{tabular}{lccc}
\multicolumn{4}{c}{ TABLE-3 } \\
ROBUSTNESS DATA FOR ADO-TRASTUZUMAB EMTANSINE \\
\hline \multicolumn{1}{c}{ Parameter } & $\mathrm{R}_{\mathrm{t}}$ & $\begin{array}{c}\text { Theoretical } \\
\text { plates }\end{array}$ & Asymmetry \\
\hline $\begin{array}{l}\text { Decreased flow rate } \\
(0.8 \mathrm{~mL} / \mathrm{min})\end{array}$ & 3.920 & 13834 & 1.17 \\
$\begin{array}{l}\text { Increased flow rate } \\
(1.2 \mathrm{~mL} / \mathrm{min})\end{array}$ & 2.726 & 11801 & 1.17 \\
$\begin{array}{l}\text { Decreased temperature }\left(20^{\circ} \mathrm{C}\right) \\
\text { Increased temperature }\left(30^{\circ} \mathrm{C}\right)\end{array}$ & 3.208 & 12638 & 1.16 \\
\hline
\end{tabular}

slope of calibration curve). LOD and LOQ for this method were found to be 0.236 and 0.787 , respectively.

\section{Conclusion}

The present study is focused to develop and validate HPLC method for estimation of ado-trastuzumab emtansine in pharmaceutical dosage form. For routine analytical purpose it is desirable to establish methods capable of analyzing huge number of samples in a short time period with good robustness, accuracy and precision without any prior separation steps. HPLC method generates a large amount of quality data which serve as highly powerful and convenient analytical tool. The method showed good reproducibility and good recovery. From the specificity studies, it was found that the developed method was specific for ado-trastuzumab emtansine which was related to all the parameters of the methods.

\section{ACKNOWLEDGEMENTS}

The authors are thankful to the Management of Koringa College of Pharmacy, Korangi, India for providing all the necessary research facilities. 

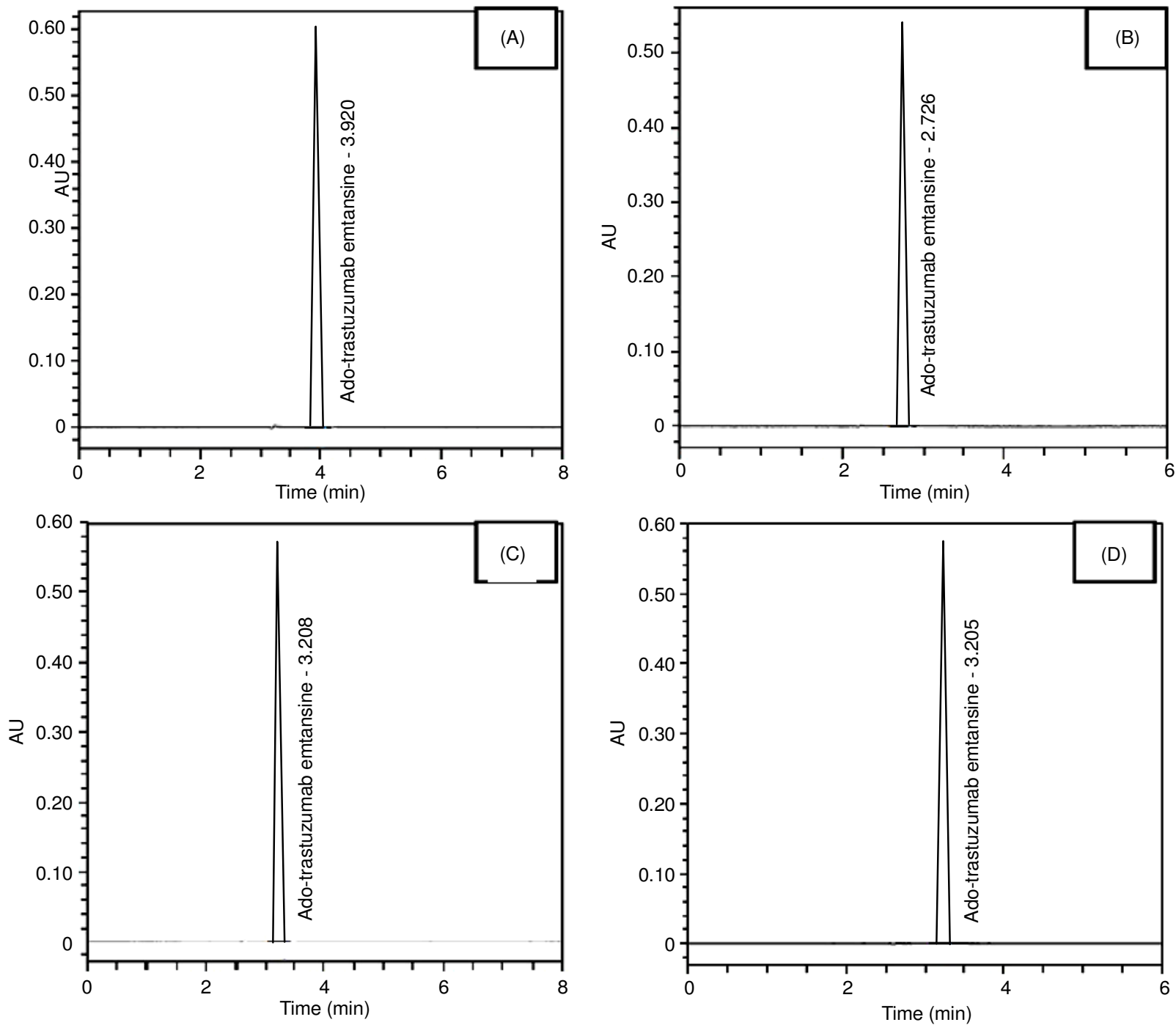

Fig. 4. Chromatogram for decreased flow rate (A), increased flow rate (B), decreased temperature (C) and increased temperature (D)

\section{REFERENCES}

1. J.M. Lambert and R.V.J. Chari, J. Med. Chem., 57, 6949 (2014); https://doi.org/10.1021/jm500766w.

2. $\quad$ P.F. Peddi and S.A. Hurvitz, Ther. Adv. Med. Oncol., 6, 202 (2014); https://doi.org/10.1177/1758834014539183.

3. G.D. Lewis Phillips, G. Li, D.L. Dugger, L.M. Crocker, K.L. Parsons, E. Mai, W.A. Blattler, J.M. Lambert, R.V.J. Chari, R.J. Lutz, W.L.T. Wong, F.S. Jacobson, H. Koeppen, R.H. Schwall, S.R. Kenkare-Mitra, S.D. Spencer and M.X. Sliwkowski, Cancer Res., 68, 9280 (2008); https://doi.org/10.1158/0008-5472.CAN-08-1776.

4. J.R. Junutula, H. Raab, S. Clark, S. Bhakta, D.D. Leipold, S. Weir, Y. Chen, M. Simpson, S.P. Tsai, M.S. Dennis, Y. Lu, Y.G. Meng, C. Ng, J. Yang, C.C. Lee, E. Duenas, J. Gorrell, V. Katta, A. Kim, K. McDorman, K. Flagella, R. Venook, S. Ross, S.D. Spencer, W. Lee Wong, H.B. Lowman, R. Vandlen, M.X. Sliwkowski, R.H. Scheller, P. Polakis and W. Mallet, Nat. Biotechnol., 26, 925 (2008); https://doi.org/10.1038/nbt.1480.
5. H.M. Lamb and J.C. Adkins, Drugs, 56, 1125 (1998); https://doi.org/10.2165/00003495-199856060-00020.

6. N.H. Foda and O.M.A. Gohary, Anal. Lett., 27, 2523 (1994); https://doi.org/10.1080/00032719408002659.

7. N. Mondal, T.K. Pal and S.K. Ghosal, Pharmazie, 62, 597 (2007); https://doi.org/10.1691/ph.2007.8.6305.

8. V.P. Shah, K.K. Midha, S. Dighe, I.J. McGilveray, J.P. Skelly, A. Yacobi, T. Layloff, C.T. Viswanathan, C.E. Cook, R.D. McDowall, K.A. Pittman, S. Spector, K.S. Albert, S. Bolton, C.E. Cook, S. Dighe, M. Dobrinska, W. Doub, M. Eichelbaum, J.W.A. Findlay, K. Gallicano, W. Garland, D.J. Hardy, J.D. Hulse, H.T. Karnes, R.D. McDowall, R. Lange, T. Layloff, W.D. Mason, G. McKay, I.J. McGilveray, K.K. Midha, E. Ormsby, J. Overpeck, K.A. Pittman, H.D. Plattenberg, V.P. Shah, G. Shiu, D. Sitar, J.P. Skelly, F. Sorgel, S. Spector, J.T. Stewart, C.T. Viswanathan, A. Yacobi and L. Yuh, Int. J. Pharm., 82, 1 (1992); https://doi.org/10.1016/0378-5173(92)90065-A

9. T.K. Mandal, A. Mishra, W.R. Singh, G. Dewangan and S. Hazra, J. Adv. Pharm. Technol. Res., 5, 147 (2014); https://doi.org/10.4103/2231-4040.137448. 